Article

\title{
Issues with Publishing Abstracts in English: Challenges for Portuguese Linguists' Authorial Voices
}

\author{
Joana Vieira Santos ${ }^{1, *}$ and Paulo Nunes da Silva ${ }^{2}$ \\ 1 CELGA-ILTEC, Department of Languages, Literatures and Cultures, Faculty of Arts, University of Coimbra, \\ 3001-401 Coimbra, Portugal \\ 2 CELGA-ILTEC, Department of Humanities, Universidade Aberta, 1269-001 Lisboa, Portugal; \\ paulo.silva@uab.pt \\ * Correspondence: jovieira@fl.uc.pt; Tel.: +35-123-985-9900 (ext. 4286)
}

Academic Editor: Margaret Cargill

Received: 24 January 2016; Accepted: 19 April 2016; Published: 22 April 2016

\begin{abstract}
This paper assesses the impact of publishing abstracts in English in the Portuguese Linguistics Association (APL) Proceedings from 2001 to 2010. The study was carried out with a corpus of 137 abstracts, follows a Text Linguistics model inspired by the Interactionnisme Sociodiscoursif and links text features to the social practices and genre repertoires of this community. Quantitative data show signs of a "Portuguese identity" in authors' voices such as personal forms, move signaling, long sentences, profuse embedding, heavy subjects, and variations in content selection, but also signs of standard academic guideline-indexed choices in impersonal forms, template sentences, coordinated constituents, nominalizations, and conventional text plans. Standard genre models and writing features from "core" academic communities coexist with alternative and traditional ways of writing and of disseminating knowledge, which is typical of a semiperipheral non-native English-speaking community torn between conflicting language and cultural paradigms. These contrasting tendencies are linked to identity changes within the community, as APL authors try to achieve international recognition by publishing abstracts in English as a Foreign Language. Since the APL research topic is the Portuguese language, the process mirrors the authors' struggle between standard internationalization in English and individual stance in Portuguese.
\end{abstract}

Keywords: publishing; English; Portuguese; abstract; genre; academic discourse

\section{Introduction}

The paper's main goal is to help in understanding issues with publishing in English in Portugal, through an analysis of abstracts in the Associação Portuguesa de Linguística or Portuguese Linguistics Association (APL) Proceedings. This academic community provides an ideal setting for the research topic because, as all members of other academic communities, Portuguese linguists aim to be known in international forums. Their research findings must be published in English, especially in a widely-read genre such as the abstract. Therefore, Portuguese linguists face the challenge of writing academic texts in an additional language. Although the issue concerns all non-native English speaking authors as they negotiate the occupation of publishing spaces alongside native speakers ([1], pp. 125-126, [2], pp. 79-80, [3], p. 42), the case of Portuguese linguists is peculiar, due to conflicting conventions yet to be fully explained, both in genre models and in writing in a non-Romance language.

The pivotal role of English as a dominant language in research has originated a wide gap between native-speaking and non-native-speaking academic communities. This issue has furthered works about each language impact in knowledge dissemination and the actual lingua franca status usually accepted for English ([4], pp. 93-109, [5], p. 347, [6-8], pp. 33-59, [9,10], p. 248, [11-17]). More specifically, several contrastive works have addressed the issue of writing abstracts in English in 
academic communities whose members speak a Romance language and have alternative rhetorical traditions [18-25]. However, there is no systematic monitoring of Portuguese speaking academic communities, despite the fact that their texts present peculiar linguistic features not found in English academic genres ([26], p. 23, [27], pp. 27-32) and also despite the fact that these features may even point to major difficulties in adapting Portuguese sentence-structures or text-structures to an alien language [28,29].

Portugal's geographical and symbolical location is crucial to grasp how smaller academic communities are situated in a globalized English-speaking world. Since Canagarajah's work [30], the links between geographical location, economic wealth, and knowledge production have been well established $([1,10]$, i.e.). These links affect publishing as well, because knowledge dissemination depends largely on material resources. As a consequence, wealthier countries are the "core" or centre of research production and dissemination, whereas poorer countries belong to a periphery that has little or no influence at all [2]. Researchers and reviewers from core Anglophone countries are in a position to dictate parameters to their less-privileged "peers", thus imposing not only standard research criteria, but also standard genre models, writing parameters, and publishing guidelines ([10], p. 251, [31], pp. 1-3).

However, this background has recently been revised, in the sense that there is also a middle or "semiperipheral" location. Researchers belonging to discourse communities in this geographical and symbolic location play a mediation role in disseminating alternative values and paradigms and in conveying means from the core to the periphery ([31], pp. 2-3). This is the case of the APL community, to which a vast majority of Portuguese linguists belong. For reasons akin to those already pointed out by Spanish linguists ([13], pp. 19-20), English is increasingly becoming the dominating language in Portuguese academia. Like in Spanish peer-reviewed journals, in an effort to boost international recognition ([2], p. 81), guidelines of Portuguese peer-reviewed journals in linguistics admit or even encourage publication in English. Therefore, the APL replicates standard core values both in research work and in knowledge dissemination. At the same time, as all semiperipheral communities, the APL preserves, to a certain extent, alternative ways of doing research and of writing academic texts ([27], pp. 15-23, [32]). Abstracts written by Portuguese linguists for publication in APL Proceedings also show features of "traditional" models, especially in the case of authorial voice and of text structure. Their analysis thus helps to highlight publishing issues in a semiperipheral community.

Finally, the focus of the present paper also helps in understanding issues of publishing in English because the research topic of the APL abstracts is the Portuguese language itself, which has circa 244 million speakers around the world ([33], p. 30). This is closely linked to a personal dilemma amongst Portuguese linguists, one that may be shared by other non-native English-speaking linguists ([3], p. 40, [14], [34], p. 102). As authors, they must abide by APL guidelines for publication. Therefore, they have to deal with an additional language and with genre models not embedded in Romance traditions ([26], p. 10). This may boost the circulation of their research articles and attract visibility to their community, but, on the other hand, it affects linguistic diversity ([10], pp. 251-252), downplays the importance of Portuguese as an academic language, and lessens its impact in knowledge dissemination ( $c f .[14]$, p. 74).

Several questions then arise: how do Portuguese linguists cope with these issues? Do they follow traditional Portuguese models or international genre models? When they write their abstracts in English, do they keep the stylistic, grammatical, and genre-specific features of a Romance language such as Portuguese or do they comply with the features of the alien lingua franca? How do these choices reflect the APL semiperipheral location in knowledge communication?

Bearing in mind these questions, the article analyses 137 abstracts published in the Portuguese Linguistics Association Proceedings between 2001 and 2010, according to their respective languages (Portuguese or English). All texts were scanned for relevant features. English sentence-structures were also compared with Portuguese sentence-structures, in order to identify features that might be language-related. Although quantitative data in Portuguese abstracts is scarce, the results help to 
highlight the impact of APL guidelines on abstract writing and on the genre itself. More specifically, they help to link the social and discursive practices of this semiperipheral academic community to issues in publishing English abstracts about Portuguese.

\section{Theoretical and Methodological Framework}

The theoretical framework combines different assumptions, in order to provide a comprehensive background to abstract analysis. It follows core assumptions of the "Interactionnisme Sociodiscursif" (ISD), a human action theory which states that language mediates and regulates human activities ([35], pp. 11, 42-43). As this statement clearly matches cornerstone concepts established by Swales for genre analysis in the context of English for Specific Purposes (ESP) and of English for Academic Purposes (EAP) [4,8], this section compares both frameworks before discussing the methodological background.

Within the ISD, verbal actions like academic texts are central, as they allow and promote social interaction and are the result of a continuous socialization process. Each text necessarily interacts with others synchronically and diachronically ([35], p. 38). Furthermore, all texts are embedded in a specific social and professional situation. This includes not only temporal and spatial dimensions, but also status and relationships of participants and goals they want to achieve. All texts emerge within a particular "formation sociodiscursive" ([35], pp. 140-141), i.e., a discourse community whose members share a set of social and professional activities.

Similarly, according to Swales, members of a discourse community share public goals and mechanisms of intercommunication ([4], pp. 24-32). Socially and historically, every discourse community has a repertoire of genres that helps members to interact with each other and to reach specific purposes. Genres, then, are defined by both authors as socio-historically rooted text models, available for all members within a particular discourse community, and linked to their social and professional activities in the sense that they help them to accomplish communicative purposes ([4], pp. 41, 45-46, [35], pp. 11, 34). For instance, in the case of an academic discourse community such as the APL, disseminating the results of research on linguistics includes genres such as abstracts, research articles, calls for papers, peer-reviewers' comments, or cover letters, amongst others.

Genres are conceptual a posteriori categories ([4], p. 39]), i.e., they are abstract entities that can only be described through analysis of actual texts ([35], p. 79). Mutatis mutandis, Bronckart's opposition between the abstract nature of genres and the empirical nature of texts is very similar to the distinction between type and instance stressed by Swales ([4], p. 42, [8], p. 17). Also, in order to account for the influence of social contexts on text production, the ISD privileges a descendent methodological approach that is shared with those applied within ESP and EAP ([8], pp. 72-73). Describing a specific genre thus relies on heterogeneous criteria that include the area of social activities, social or professional roles, and pragmatic goals.

On the other hand, genre analysis should combine this top-down approach, which goes from the discourse community's social practices to the material dimension of text analysis ([35], p. 103), with a bottom-up approach, to assure a comprehensive description of typical textual properties [36-38]. However, neither Bronckart nor Swales methodologies provide a detailed step-by-step procedure for analysing concrete features in specific subsets of texts. (Swales proposals of a text-driven procedure for genre analysis ([8] p. 74) regroup textual features in a general step entitled "structure + style + content + "purpose". These broad categories are too general to be useful for the present analysis). This is the main reason why contributions both from Text Theory [38] and from Text Linguistics [36,37] are needed, in order distinguish genre from text.

Coutinho \& Miranda [38] propose the concepts of "genre parameters" and of "textual realization mechanisms" (or devices). This distinction reflects the difference between inferred genre properties and unfolded text properties. Genre parameters are the typical properties of a specific genre. They are predictable features that help to build up a given genre's identity and to distinguish it from other genres. On the other hand, textual realization mechanisms are devices that materialize genre parameters. 
They may be recognized whenever they appear in a reasonable number of texts. A particular parameter may be supported by several devices and vice-versa. For instance, in the APL corpus, text contraction up to 100 words and placement immediately before the main text are textual realization devices that materialize genre parameters such as limited length and strategic initial position.

Table 1 summarizes the main theoretical concepts and relates them to the abstract and to the empirical plans of analysis.

Table 1. Levels and concepts of analysis.

\begin{tabular}{ccc}
\hline & Abstract Plan & Empirical Plan \\
\hline $\begin{array}{c}\text { Object of analysis } \\
\text { Properties }\end{array}$ & Genre & Text \\
\hline
\end{tabular}

It should be stressed that some textual realization devices have a distinctive value, as they appear exclusively in texts of a particular genre and clearly identify it. These devices are "genre markers" that function like clues. They may be either self-referential or inferential, depending on whether they directly state the genre of a specific text or they allow speakers to infer the genre ([38], pp. 40-43). The label abstract (or resumo in Portuguese) is a self-referential marker, whereas the title of the research article or paper and the list of key words, which occur immediately before and after the abstract, are inferential markers that establish ad quem and a quo textual boundaries.

Since textual devices are infinitely variable, organising them is an unavoidable task for establishing parameter settings, especially in specific subsets of texts. For this reason, the present paper also adopts Adam's typology of textual components, or composantes textuelles: (i) enunciation-author's social and professional roles, as well as situational features such as time and space (geographical, social, etc.); (ii) pragmatics-author's general and specific goals, such as being published or convincing readers of the research claims; (iii) compositional structure-text plans, text sectioning, and sequence types (such as narrative, descriptive, etc.); (iv) semantics-content selection and the fictional or non-fictional nature of topics; (v) stylistics and sentence structure-lexical selection and specific syntactic structures; (vi) metatextual-textual self-references and the relevant discourse community's conceptions on the genre that the text belongs to; (vii) peritextual—textual boundaries; (viii) material—media, text extension and, in written texts, formatting ([36], pp. 40-41). These categories cover all relevant dimensions of genre criteria and they may either be internal or external ([37], pp. 195-196).

Specific subsets of textual devices may be indexed to specific genre parameters. In the case of the present article, author's voice and text plans were chosen as the main parameters, because an authors' professional role and pragmatic goals belong to his or her external identity as a Portuguese linguist. Identities are reflected in internal textual devices related to voice.

In oversimplified terms, "author's voice" means "a writer's unique and recognizable imprint", i.e., several ways through which an author marks his or her presence in a given text ([39], p. 37). It is thus related to academic stance, or the researcher's claims [40], which, in the case of linguistics, are very often based on research results. However, in more accurate terms, voice is a double concept that includes an individual and a social perspective as well [39] (Although voice may also have a dialogic perspective [39], this dimension is not taken into account in the present work, since some of its instances, like the referees' points of view, are unaccounted for).

Individual perspective is linked to an author's identity, unique educational background, and specific writing experiences. It may be marked by similar linguistic features in all texts written by the same person, irrespective of readers or communities. By contrast, social or collective perspective is the way through which the author negotiates his or her admission to a specific community $([39,41]$, p. 245$)$. In the case of academia, as Hyland argues, " (. . ) taking on a voice associated with a particular field of study involves aligning oneself with its knowledge-making practices: the topics it believes are worth talking about, and how it talks about them. Acting as 
academics, individuals attempt to embed their talk in a particular social world which they reflect and conjure up through the discourses which others anticipate and understand." ([42], p. 15).

Pragmatic goals may then become more relevant than individual preferences, as authors, in order to achieve publication, replicate whatever textual devices the community is used to or imposes in a particular genre. As a consequence, "the voice of a text is created within a social context; the social voices of that context are part of the writer's repertoire from which he or she may draw when selecting words, phrases, grammatical structures, [or] organizational patterns ( ... )" ([39], pp. 38-39). This may also be seen in text plans.

To sum up, in order to treat both genres' abstract properties and texts' empirical features, the present analysis relies on three key concepts: genre parameters, textual realization devices, and genre markers [38]. Furthermore, the adopted model includes these concepts in a comprehensive typology of external and internal categories ([36], pp. 40-41) linked to authors' voices and text plans (see Section 4).

\section{Corpus and Methodology}

The corpus includes 137 texts up to 100 words. All texts are available online (see http://www.apl.org.pt/actas.html) and they are also published in the printed versions of the APL Proceedings. They were firstly organized according to their year of publication (see Table 2):

Table 2. Papers and abstracts (2001-2010) (The year of the meeting and the year of publication are given in square brackets, because Proceedings volumes are published one year after each APL meeting. The present article considers publishing policies between 2001 and 2010, since rules for submitting abstracts are laid out in the year of the meeting. Also, at least some of these abstracts are published in the version previously submitted to the meeting (personal communication). Quotations display subsequent publishing dates (2002-2011). References for quoted abstracts (see Section 4) may be found on the Appendix).

\begin{tabular}{|c|c|c|c|c|c|c|}
\hline \multirow{2}{*}{$\begin{array}{l}\text { Proceedings } \\
\text { Volume }\end{array}$} & \multirow{2}{*}{$\begin{array}{l}\text { Number of } \\
\text { Papers }\end{array}$} & \multirow{2}{*}{$\begin{array}{l}\text { Number of } \\
\text { Abstracts/ } \\
\text { Résumés/ } \\
\text { Resumos }\end{array}$} & \multirow{2}{*}{$\begin{array}{l}\text { Percentage } \\
\text { of Abstracts/ } \\
\text { Résumés/ } \\
\text { Resumos }\end{array}$} & \multicolumn{3}{|c|}{$\begin{array}{l}\text { Distribution of Abstracts } \\
\text { Throughout the Decade }\end{array}$} \\
\hline & & & & Papers & Abstracts & Percentage \\
\hline 17 [2001-2002] & 45 & 3 & $6.6 \%$ & & & \\
\hline 18 [2002-2003] & 77 & 3 & $3.8 \%$ & & & \\
\hline 19 [2003-2004] & 54 & 1 & $1.8 \%$ & & & \\
\hline 20 [2004-2005] & 61 & 0 & $0 \%$ & 365 & 12 & $3.2 \%$ \\
\hline 21 [2005-2006] & 46 & 3 & $6.5 \%$ & & & \\
\hline 22 [2006-2007] & 47 & 1 & $2.1 \%$ & & & \\
\hline 23 [2007-2008] & 35 & 1 & $2.8 \%$ & & & \\
\hline 24 [2008-2009] & 38 & 38 & $100 \%$ & & & \\
\hline 25 [2009-2010] & 46 & 46 & $100 \%$ & 125 & 125 & $100 \%$ \\
\hline 26 [2010-2011] & 41 & 41 & $100 \%$ & & & \\
\hline
\end{tabular}

Data show a distinctive difference in the last three years, highlighted on the last three columns. 125 out of 137 abstracts (i.e., 91.2\%) belong to the meetings that took place in 2008, 2009, and 2010, and only $12(8.8 \%)$ occurred in the previous seven years. As this is closely linked to publishing guidelines concerning not only the abstract, but also its language, language choice before 2008 and language prescription after 2008 was the second relevant feature to be considered.

In the total amount of 137 abstracts, 127 are written in English, 9 in Portuguese, and 1 in French. It may seem that APL authors prefer English to express their stance, but this is true only after the XXIV $^{\text {th }}$ meeting, which took place in 2008. Between 2001 and 2007, only 12 abstracts are provided, most of them written in Portuguese (see Table 3). 
Table 3. Abstracts' languages.

\begin{tabular}{cccccc}
\hline \multirow{2}{*}{$\begin{array}{c}\text { Abstracts } \\
\text { Periods }\end{array}$} & Papers & \multirow{2}{*}{$\begin{array}{c}\text { Abstracts } \\
\text { /Résumés/Resumos }\end{array}$} & English & Portuguese & French \\
\cline { 4 - 6 } & & 12 & 2 & 9 & 1 \\
$2001-2007$ & 365 & 125 & 125 & 0 & 0 \\
\hline $2008-2010$ & 125 & & &
\end{tabular}

All earlier abstracts are either Portuguese texts or English translations. However, after 2006, the reviewing committee provided specific guidelines in the call for papers, stating that proposals should indicate the research theoretical background, aims, method(s), and results, in an IMRD research article organization ([21], p. 284). The most important guideline was issued in 2008, when an abstract in English became a condition to publication in the Proceedings. This is the main reason why there is such a discrepancy in the number of abstracts throughout the decade, as shown in Table 2.

In order to assess this effect, abstracts were also thoroughly searched in order to find relevant textual realization devices [38]: (i) personal and impersonal forms; (ii) text moves; (iii) epistemic markers; (iv) sentence structure; (v) text plans. Whereas (i), (iii) and (iv) are stylistic and sentence-structure devices, (ii) and (v) are compositional devices that imply semantic choices ([36], pp. 40-41). Bearing in mind the gap between the two periods shown in Table 3, all devices were counted in each text and considered contrastively over the decade, so as to retrace significant changes. Accordingly, each device found in at least four English abstracts was compared to the corresponding one in abstracts published before 2008 in Portuguese. As there are only 12 texts for the period before 2008, these were considered together. The basic units for calculations are the text, the sentence and the number of words per period.

\section{Analysis and Discussion of Results}

\subsection{Personal and Impersonal Forms Choices and Text Moves}

Self-mention devices such as personal pronouns and personal verbal forms occur in 9 out of the 12 pre-2008 texts, seven of them with mixed impersonal forms. Personal pronouns appear only in one of the two English abstracts, in the first person singular I. Self-mention is marked by the use of the corresponding verbal forms in Portuguese texts. As European Portuguese is a null subject pro-drop language with rich inflectional morphology ([43], p. 15), the use of first person singular or plural in verbs is thus language-related. On the other hand, both English and Portuguese abstracts also exhibit occasional clitics and possessives in a first person form such as nosso-nossa-nossos - nossas (our), nos (to us) - me (to me).

These devices belong to a "traditional" Portuguese rhetoric model, since they indicate a high degree of authorial presence, especially in the case of the first person singular ([20], p. 141). They point to a peculiar adaptation of the genre parameter "author's voice" within the APL community. As self-mention forms, they allow authors to establish a close connection to their own texts and "to make a personal standing and to separate their work from others" ([42], p. 19). Authors thus assume either the role of "opinion-holders" or of "originators" ([3], pp. 47-48, [44], p. 70):

(1) “( . . ), procurarei enunciar os objetivos e as estratégias que considero ( . . ) [(I) will try to present the aims and the strategies that (I) consider ( . . ) ] ( . . )." (2003, p. 539)

(2) "In this paper $\underline{I}$ will be considering ( . . ). I will claim that both arguments ( . . )." (2003, p. 729)

The use of plural forms is much more frequent than the singular forms throughout the decade (72 texts with plural personal forms and only 4 with first person singular). Plural forms appear in the exclusive variety, when authors refer to the researcher and exclude the reader ([20], pp. 145-146). 
This device helps to enhance the credibility of whoever is responsible for the research and it is resilient enough to appear both in earlier and in later texts, very often in the textual move presenting the claims:

(3) “( . . ). Tentaremos essencialmente explicar as diferenças ( . . ). Abordaremos também [We will essentially try to present the differences ( . . . ). We will also present] ( . . )." (2003, p. 303)

(4) "The aim of this paper is to argue about the compatibility (...). In the framework of Cognitive Linguistics, we will discuss (... ). First, we will show that (...). Second, we will indicate the main reasons ( ... ). Finally, we will identify the contributions ( ... ) and will present the guidelines for a research (... )." (2009, p. 511)

Exclusive we is used after 2008 only for signaling different moves. Other instances of first person plural are inclusive ([20], pp. 142-143) and representative ([3], p. 47). They usually mark the move establishing a theoretical framework/defining critical concepts. This device allows authors to tone down their individual voices by assuming a position shared by other researchers, which in turn helps to strengthen their claims. In a way, it signals a general assumption of an entire academic community ([20], p. 143). It occurs on a much smaller scale than exclusive we ( 0 occurrences before 2008 and 8 after), though it is especially visible in single-authored abstracts:

(5) "There is an increase of functional projections in the Left periphery when we add interpretative value to a construction ( . . )." (2009, p. 61)

Throughout the decade, changes in verbal forms often signal move changing. Personal forms then appear in the same text, sometimes in the same sentence, alongside passive voice, third person verbal forms with inanimate subjects and impersonal forms with reflexive constructions and indeterminate subjects:

(6) Move 1 [Topic presentation]

“Nesta comunicação são discutidos alguns casos ( . . . )"

[litt.] In this paper are discussed several cases

Move 2 [Text plan presentation]

“( . . ) Em primeiro lugar, damos conta dos resultados ( . . )"

[litt.] Firstly, (we) account for the results

Move 3 [Results presentation]

“( ... Todas as descrições são feitas $(\ldots) . "$

[litt.] All the descriptions are made (2002, p. 419)

After 2008, the total amount of personal forms is 149. Out of 125 texts, 65 mix we/I $+\mathrm{V}$ or our, me, us with impersonal structures such as It is + Adj, third personal verb forms and passive structures with non-animate subjects (52\%). This is slightly lower than the percentage of mixed texts before 2008 (7 out of 12 , i.e., $58.3 \%$ ), but texts bearing only impersonal structures also become more frequent (55 out of 125 , i.e., $44.0 \%$, and 2 out of 12, i.e., 16.6\%). This last result matches the use of epistemic markers of evidentiality, sometimes with evaluative and "subjective adjectives":

(7) "The annotated dialect corpus CORDIAL-SIN provides straightforward and systematic access to a compilation of spontaneous and semi-directed speech from European Portuguese dialects. Optimal inquiry for precise morphological and syntactic information throughout this corpus is granted by two layers of annotation ( ... ) which are automatically searchable for linguistic labels and structure through independently available tools. This paper concentrates on issues (... ). Ultimately, the text casts light on the potential of the CORDIAL-SIN corpus as a tool for (dialect) syntactic inquiry." (2010, p. 225) 
(8) "There is considerable evidence supporting the benefits of extensive reading ( . . )." (2009, p. 331)

Markers of evidentiality also become more frequent after 2008. There is a total of 73 in the 12 abstracts before 2008 (average of 6.08 per text and 1.40 per sentence), whereas there are 887 after 2008 (total average of 7.09 per text and 1.97 per sentence in the last three years). These devices suggest objective data that exists independently of the author's point of view. Although this may be similar in French-written abstracts that are considered "informative" ([18], p. 98), in fact the devices enhance the topic and enable authors to establish a wider distance vis-à-vis their texts by "downplaying [their] personal role in the research" ([42], p. 18; see also [3], p. 54, [45], p. 161, [46], pp. 136-137). Therefore, they point to a shift from a hermeneutic position about knowledge towards a more empiricist one ([27], p. 34). By doing this, Portuguese linguists abide by the reviewers guidelines and favor more standardized and international research criteria in Humanities, like other non-native English-speaking researchers [41]. As a result, individual voice becomes inaudible and authorial visibility gives way to aseptic writing, although this is rare in the so-called "soft sciences". Due to its popularity, by the end of the decade, authors' voices are so toned down by distancing features that they become a mere collective vehicle for disseminating foregrounding "facts".

Within academic genres, the corresponding parameter may be called the text's "self-enunciation". In the APL corpus, this is shown by changes throughout the decade from personal to impersonal forms, from marking authorial presence to building up a reality effect. This evolution closely follows the change in language choice (see Table 3), since English abstracts from later years present a striking resemblance in the use of these devices. Moreover, this resemblance is also evident in sentence-structures (see next section)

\subsection{Sentence Structure}

In earlier abstracts in Portuguese, there are several "distinguishing discourse features", i.e., linguistic devices that are either language-indexed or typical of the more traditional "complex syntax" of Portuguese academic texts ([26], pp. 44-60, [27], pp. 27-31). Firstly, sentence length is longer than in standard English. This is especially visible after 2008, even if the average number of words per sentence slightly decreases (28.92 words per sentence before 2008, and 26.50 after 2008). Secondly, sentence-structure freely uses embedded subordinate finite clauses with the subjunctive, relative clauses and non-finite clauses with infinitive, participial or gerund verb forms. Thirdly, since Portuguese is a null-subject language, there is the possibility of subject-verb inversion and subjects may be considerably heavy.

The same devices are present in English abstracts, which are clearly translations of these Portuguese sentence-structures to an "alien" language. This is obvious in embedded subordinate clauses that encapsulate the main structure Subject + Verb. Many English abstracts thus show profuse embedding and heavy constituents, such as in (9):

(9) "Taking as reference an oral corpus consisting of verbal interactions presented in Portugueseradio phone-in programmes, we analyze the emergence of conversational narrative in interactive oral discourse, highlighting the semantic and pragmatic aspects to co-constructinteractional meaning and referring the specific processes of definition of the discursive identities here in question." (2011, p. 35)

As seen in (9), English abstracts from later years do not exclude these devices. Nevertheless, they usually present less-complex sentences with more coordinated constituents. In the 12 abstracts published before 2008, there is a total of 52 sentences, with 65 subordinate clauses and only 5 occurrences of coordinate clauses. In the other 125 abstracts, there are 450 sentences, with 550 subordinate clauses and 121 coordinate clauses. On average, abstracts have a rate of 1.25 subordinate clauses per sentence before 2008 and of 1.20 after 2008, but rates for coordinate clauses per sentence are 0.09 before 2008 and 0.26 after 2008 . 
Also, there is a slight increase in nominal phrases with more than 4 words, i.e., linguistic features that are more common in English mainstream academic texts [47] (0.81 per sentence before 2008 and 0.93 per sentence after 2008):

(10) " (. . ) Taking into account subject-verb word order in gerund clauses of standard and non-standard Contemporary European Portuguese, we argue that word order in gerund clauses is not directly related to the null subject parameter." (2011, p. 256)

Abstracts after 2008 also present striking resemblances in descriptive incipit sentences, with an overwhelming tendency to use a template-sentence with a Noun phrase [Demonstrative + Noun] + Verb Phrase [Verb in the present + Noun], as seen in the following examples (chosen from a total of 28 occurrences in 125 texts):

(11) “This paper discusses evidence ( . . )." (2009, p. 97)

(12) "This paper discusses the variable use of subjunctive ( . . )." (2010, p. 143)

(13) “This paper describes the preposing of locative adverbs ( . . )." (2009, p. 225)

(14) "This paper describes the CINTIL-Treebank Online Searcher ( . . )." (2010, p. 465)

(15) "This paper investigates the semantics of Portuguese nominal modifiers ( ... )." (2009, p. 315)

(16) “This paper analyzes a type of structurally complex time adjuncts in Portuguese ( ... )." (2010, p. 623)

It seems that the compulsory inclusion of an abstract in English from 2008 onwards has encouraged authors to use less-elaborated structures, as well as template-sentences, in order to signal to the reviewing committee their compliance with an international model of the genre. Notwithstanding the risks of assigning ulterior motives or implicit values to an entire disciplinary community, it may be argued that its members have chosen these standard devices in order to be published, or, to put it in a more elegant way, to obtain visibility, firstly for themselves, secondly for their research and, by extension, for their subject of research, the Portuguese language. It is thus an interesting paradox that this is plausibly achieved by erasing some original genre features that may have been previously present in their voices. This can also be seen through text plans (see next section).

\subsection{Text Plans, Content, and Section Ordering}

Analysis of semantic and compositional components is focused on selected contents and text plans, i.e., in the order in which they are presented in the abstracts. While making a plan, authors need to be both accurate in content selection and ingenious in their display, so that they may "sell" the paper to the reviewing committee within a very short text-length ([19], p. 26, [45,48], p. 182). Therefore, they follow publishing guidelines about including the theoretical background (through the mention of references), methodology and results, aims or claims (see Section 3).

Text plans also include linking contents (for instance, in sequence types, such as narrative, descriptive, etc.) and devices of textual division such as sentences and paragraphs that help to organize semantic contents [37]. Since the APL abstracts have no segmentation other than sentence-division, analysis mainly targeted the type of contents included in the texts. As seen in previous devices, these show differences in the abstracts written before and after 2008.

Each content, such as topic, aims, references, or paper structure may be regarded as a part of the abstract. In this sense, contents are non-segmented sections within each abstract. However, contents are also selected by the author in order to express his or her goals. In this sense, contents are rhetorical moves, or, at least, steps that contribute to make a rhetorical move, such as introducing a purpose, situating the research, describing the methodology, presenting topics, references, claims, or conclusions [29]. 
More precisely, APL authors make their selection amongst 11 types of non-fictional contents issued from the paper: topic, claims, aims, assumptions, hypothesis, problem/issues, methods, theoretical framework, references, corpus, and paper structure. Each abstract usually presents between two and four of these contents, as in the following examples:

(17) [Assumption] “Capeverdean (CV) is a non pro-drop language (Pratas, 2007): no null referential subjects in matrix clauses are allowed in adult grammar.

[Topic + Results] This paper presents the results of the first experiment (elicited production task) with young CV speaking children in Santiago Island.

[Claims] As in other non-pro-drop languages, some instances of early Null Subjects have been observed. It is proposed that CV children have correctly set the value of the Null Subject parameter (negative), but their early grammar offers the option of a clause root at a lower level than $\mathrm{CP}$

[Reference] (truncation hypothesis, Rizzi, 1994; 2000), which allows for subject omission." (2009, p. 367)

(18) [Topic] "This paper examines the competence of heritage speakers of Portuguese living in Germany with respect to clitic placement in Portuguese

[Method] by comparing their performance with that of monolingual speakers of the same age (7-15 years of age) in a test designed to elicit oral production data.

[Claims] The results of the study indicate that the heritage speakers go through stages in the acquisition of clitic placement that are similar to those of monolingual acquirers even though they take longer to attain the target grammar." (2011, p. 81)

This suggests that abstracts are a rigid, conventional genre, as there is a small group of contents that may be selected. These are necessarily prominent contents taken from the paper and, at the same time, contents that may convince the reviewers that the research paper is worth publishing ([20], p. 5, [21]). On the other hand, abstracts show an enormous variety both in the actually selected contents and the order in which they are textually presented. Among the 137 APL abstracts, $52(38.0 \%)$ have a singular plan, and 85 abstracts $(62.0 \%)$ share common text plans. The top four types of text plans are the following:

- $\quad$ Topic + claims (16 abstracts- $11.6 \%)$;

- Topic + aims + claims (11 abstracts-8.0\%);

- $\quad$ Topic (7 abstracts $-5.1 \%)$;

- Assumptions + topic + claims (6 abstracts-4.3\%).

Other 17 text plans were adopted in more than one abstract, such as topic + aims (four abstracts), topic + assumptions + claims (four abstracts), and topic + references + claims (four abstracts).

Nevertheless, a standardization process such as the one already mentioned about the incipit sentence structure may be in progress. There were four top-selected contents before 2008: topic, aims, claims and assumptions. Within the first time-span, presenting the topic occurs in 11 out of 12 abstracts (91.6\%), presenting the aims and presenting the claims both occur in 5 of 12 abstracts (41.6\%). Finally, presenting the assumptions occurs in 4 of the 12 abstracts (33.3\%), as in the following examples:

(19) [Presenting the topic] "Neste artigo, apresentamos os últimos avanços e resultados obtidos [In this article, (we) present the last developments and results] ( . . )." (2007, p. 141)

(20) [Presenting the aims]: “( . . ) Esta reflexão tem por finalidade o estabelecimento de uma caracterização do conceito [This reflection aims to establish a characterization for the concept] ( ... )." (2006, p. 169) 
(21) [Presenting the claims] “( . . ) A caracterização sociológica dos dois tipos de textos mencionados opõe-se: enquanto que o político dissimula, a função social declarada da imprensa é a de dilucidar e, mesmo, polemizar os temas. ( . . )." [The sociological characterization of the above mentioned two text types is opposed: while political text type mainly disguises, the declared social function of the press is to elucidate and to discuss controversial subjects] (2002, p. 345)

(22) [Presenting the assumptions] "Em línguas como o Português Europeu existe um vasto conjunto de verbos que seleccionam orações completivas de tipo infinitivo ( ... )." [In languages such as European Portuguese, there is a vast set of verbs that select infinitive complement clauses] (2006, p. 303)

However, from 2008 onwards, i.e., after abstracts in English became mandatory, there are only two top-selected contents, presenting the topic and the claims:

(23) [Presenting the topic] "A study aiming at assessing nominal agreement skills of SLI children speaking European Portuguese was conducted with 8 SLI children, aged 4 to 8 years old, in a picture-selection comprehension task and in an elicited production task using nouns and pseudo-nouns." (2011, p. 111)

(24) [Presenting the claims] “( . . ) Parenthetical coordinate sentences have a different behavior in what concerns their relationship with the host: they may be anchored into a constituent or float within the host sentence. ( ... ) We claim that they are basically inserted, by External Merge, as left adjuncts of the verbal and sentence functional positions of the host sentence." (2010, p. 607)

After 2008, presenting the topic occurs in 111 out of a total of 125 abstracts $(88.8 \%)$, and presenting the claims in 98 texts $(78.4 \%)$. By contrast, before 2008, presenting the claims has only occurred in 5 abstracts out of a total of 12 analyzed texts (41.6\%). This suggests that, from 2008 onwards, it has become a central topic for the APL researchers, one that they often select and include in their abstracts. Two reasons may help to explain this change.

Firstly, it may be argued that, in Portuguese academic writing tradition, at least in the Humanities, compositional plans of argumentative texts were standardized in three parts that included an introduction, a development, and a conclusion. Like other Romance writing traditions, this has earmarked Portuguese argumentative texts. Portuguese authors had a tendency to present their claims in the final section of the paper, and did not anticipate them, either in the abstract or in the introduction. This is probably the reason why most abstracts written before 2008 did not include the claims. The abstract appeared before the paper, whereas authors were used to present the claims only at the end of the paper, after discussing other contents such as topics, aims, theoretical frames, methodologies, analysis, results, i.e., the whole research process and the arguments that supported the claims. The last were preferably treated in the final section.

Secondly, authors of the abstracts written after 2008 are nowadays more aware of core academic text models and writing styles. Moreover, they often read abstracts written by APL gatekeepers. These gatekeepers are also the reviewers who judge their peers mainly through abstracts ([41], p. 244). Gatekeepers recognize a valid or invalid text and may accept or reject it for publication on the basis of compliance with the guidelines they have previously stated. Moreover, their texts function as a model that apprentices try to replicate in their own abstracts. In order to achieve the goal of publication, authors may re-use gatekeepers' distinctive internal devices like text plans, rhetorical moves and even template sentence structures. By doing so, they tune their voices to the discourse community general choir.

Like novice-researchers from other Romance-speaking communities $([13,16,19]$, p. 26), APL authors tend to adapt their own text plans to models and styles closer to what is internationally used 
and accepted, as already seen in self-mention and sentence-structure devices (see Sections 4.1 and 4.2). Changes in the abstracts' contents selection suggests that there is an ongoing process of adjusting APL abstracts to those that are published in internationally circulating linguistics journals. In that process, several devices which have been typical of this academic community are being replaced by other devices, which are typical of international models [32]. It is worthwhile noticing that selecting and displaying critical contents in a strategic order attracts not only peer-reviewers, but also peer-readers and may even boost the paper's circulation. As such, these decisions also point to the authors' compliance with the new discursive practices of their semiperipheral research community.

\section{Conclusions}

According to the results discussed in the previous sections, published abstracts over a 10-year period (2001-2002 to 2010-2011) in the APL Proceedings show different choices in linguistic devices related to voice, sentence structure, and content selection. Before 2008, that is, before English-written abstracts have become a condition for publication, personal forms, long sentences, subordinate constituents, and heavy subjects were unmistakable signs of a "Portuguese identity". With the exception of subordinate clauses, these devices become scarcer in abstracts after 2008, which also present impersonal forms, more coordinated constituents, nominal phrases, and even template-sentences usually found in English abstracts from other academic communities. Also, from 2008 onwards, most abstracts include the author's claims. Texts show that authors have gradually become closer to an international text model for the genre abstract. As a result, later APL abstracts exhibit more impersonal features, evidentiality markers, less-complex sentences, and a slightly different selection of contents, notably by highlighting the claims.

Bearing in mind this background, it may be argued that Portuguese linguists have adapted their voices throughout the decade, thus shifting towards an international model for abstracts. By 2010, it is clear that publishing stipulations have had an effect on writing practices related to authors' identities and voices. Nevertheless, individual preferences for some of these devices are more resilient than others. Together, they may be taken as unmistakable signs of a pervasive "Portuguese identity" in the APL abstracts, although this identity uses slightly different voices in the two time spans shown in Table 2. As it might be expected according to the ISD framework [35], the corpus reflects the social practices, strategic choices, and internal values of the APL.

Firstly, the use of English in abstracts shows the above-mentioned dilemma of APL members. As Portuguese researchers who study their own language, it is expected that they make their voices heard in Portuguese, in order to strengthen its status as a language for knowledge dissemination, and also that they follow whatever textual models their own community has been building up within a Portuguese-speaking context. On the other hand, they strive to be known in a globalized publishing world. Therefore, they are expected to make their voices heard in English, using devices and textual models that are instantly recognized by the core of academia, so that they achieve recognition in international contexts. Borrowing from Hyland, it can thus be said that, amongst APL authors, abstract writing is not so much an "encounter" as "a struggle" between past experience and the current context ([42], p. 147). This struggle is typical of a semiperipheral academic community in the sense that its members may be shifting towards English rhetorical models, without erasing alternative ways of researching and of disseminating research results ([27], p. 34).

Secondly, amongst APL members, discursive practices in the genre abstract were neither adopted as a rule nor clearly defined before 2008. The imposition of English-written abstracts by the APL's reviewing committee has encouraged new discourse practices which in turn have reflected new institutional values. This ongoing process aims to promote international knowledge dissemination and authors' recognition. Collected data thus point to a continuous adjustment of abstracts, which is probably not yet stabilized. In fact, many texts, even if they are now English-written, still maintain traditional writing features of Portuguese Humanities, such as the use of personal forms, long sentences, and subordinate clauses. On the other hand, these texts also present several new compositional, 
semantic, or stylistic features, which are the result of a new APL research paradigm, with new pragmatic goals.

Overall, it seems that there is a process of identity redefinition within this academic community fuelled by writing and publishing in English as a lingua franca. The process also reflects a wider transformation of the ways APL members communicate their research and plausibly of the ways they do their research, since it shows the adoption of globalized core paradigms that may help them to reach international publication and acknowledgement. The above transformations are meant to attract a wider audience and, ultimately, to make their authors internationally known and recognized. Therefore, the texts point to a growing standardization of genre and of writing and publishing practices progressively constructed by APL members themselves. Even if by doing so they strengthen their common identity as members of a semiperipheral academic discourse community, this will probably result in a more standardized identity for them, as individual stance in Portuguese gives way to collective internationalization in English.

Acknowledgments: The authors wish to thank the Fundação para a Ciência e Tecnologia (FCT), which has supported the research project of CELGA-ILTEC (I\&D 4887, UID/LIN/04887/2013, co-financed by QREN-Quadro de Referência Estratégico Nacional, COMPETE—Programa Operacional para a Competitividade e Desenvolvimento Nacional, the EU Regional Development Fund-NUTS II Regional Fund) and Horizons 2020. They also wish to thank Diana M. Silver, who has revised the English manuscript.

Author Contributions: Both authors contributed equally to this work.

Conflicts of Interest: The authors declare no conflict of interest. The founding sponsors had no role in the design of the study; in the collection, analyses, or interpretation of data; in the writing of the manuscript, and in the decision to publish the results".

\section{Abbreviations}

The following abbreviations are used in this manuscript:

$\begin{array}{ll}\text { MDPI } & \text { Multidisciplinary Digital Publishing Institute } \\ \text { DOAJ } & \text { Directory of open access journals } \\ \text { TLA } & \text { Three letter acronym } \\ \text { LD } & \text { linear dichroism }\end{array}$

\section{Appendix}

Examples (available online: http://www.apl.org.pt/actas.html (accessed on 8 January 2016)

(1) Mateus, M.H.M. Objectivos e estratégias de uma política linguística. In Proceedings of the Textos Seleccionados do XVIII Encontro Nacional da Associação Portuguesa de Linguística, Lisbon, Portugal, 2-4 October 2002; Freitas, T., Mendes, A., Eds.; APL: Lisbon, Portugal, 2003; pp. 539-544.

(2) Santos, P. Conditionals, contexts and Apartheid. In Textos Seleccionados do XVIII Encontro Nacional da Associação Portuguesa de Linguística, Lisbon, Portugal, 2-4 October 2002; Freitas, T., Mendes, A., Eds.; APL: Lisbon, Portugal, 2003; pp. 729-736.

(3) Cumbane, R.M.M. As Construções de Duplo Objecto em Xitshwa: Sua influência em falantes do português (L2). In Proceedings of the Textos Seleccionados do XVIII Encontro Nacional da Associação Portuguesa de Linguística, Lisbon, Portugal, 2-4 October 2002; Freitas, T., Mendes, A., Eds.; APL: Lisbon, Portugal, 2003; pp. 303-314.

(4) Silva, A.S.; O cognitivo e o social nos estudos linguísticos: Inimigos íntimos? In Proceedings of the Textos Seleccionados do XXIV Encontro Nacional da Associação Portuguesa de Linguística, Braga, Portugal, November 20-22 2008; Fiéis, A., Coutinho, M.A., Eds.; APL: Lisbon, Portugal, 2009; pp. 419-431. 
(5) Amaral, D.T.; Interrogativas-Wh: Periferia Esquerda e Fases. In Proceedings of the Textos Seleccionados do XXIV Encontro Nacional da Associação Portuguesa de Linguística, Braga, Portugal, 20-22 November 2008; Fiéis, A., Coutinho, M.A., Eds.; APL: Lisbon, Portugal, 2009; pp. 61-79.

(6) Rodrigues, C.; Questões de Espraiamento em PE. In Proceedings of the Textos Seleccionados do XVII Encontro Nacional da Associação Portuguesa de Linguística, Lisbon, Portugal, 2-4 October 2001; Gonçalves, A., Correia, C.N., Eds.; APL: Lisbon, Portugal, 2002; pp. 419-434.

(7) Carrilho, E.; Magro, C.; A anotação sintáctica do CORDIAL-SIN. In Proceedings of the Textos Seleccionados do XXV Encontro Nacional da Associação Portuguesa de Linguística, Porto, Portugal, 22-24 October 2009; Brito, A.M., Silva, F., Veloso, J., Fiéis, A., Eds.; APL: Lisbon, Portugal, 2010; pp. 225-241.

(8) Martins, A.M. Leitura extensiva em L2: O lugar dos textos modificados. In Proceedings of the Textos Seleccionados do XXIV Encontro Nacional da Associação Portuguesa de Linguística, Braga, Portugal, 20-22 November 2008; Fiéis, A., Coutinho, M.A., Eds.; APL: Lisbon, Portugal, 2009; pp. 331-337.

(9) Almeida, C. Aspectos semânticos e pragmáticos da co-construção de identidades discursivas em "narrativas de experiência de vida" produzidas por participantes de emissões nocturnas de rádio. In Proceedings of the Textos Seleccionados do XXVI Encontro Nacional da Associação Portuguesa de Linguística, Porto, Portugal, October 21-23, 2010; Costa, A., Falé, I., Barbosa, P., Eds.; APL: Lisbon, Portugal, 2011; pp. 35-48.

(10) Fiéis, A.; Lobo, M.; Propriedades de gerúndios e infinitivos em português antigo. In Proceedings of the Textos Seleccionados do XXVI Encontro Nacional da Associação Portuguesa de Linguística, Porto, Portugal, October 21-23, 2010; Costa, A., Falé, I., Barbosa, P., Eds.; APL: Lisbon, Portugal, 2011; pp. 256-265.

(11) Barbosa, P.; Sujeitos explícitos em orações infinitivas de controlo e elevação. In Proceedings of the Textos Seleccionados do XXIV Encontro Nacional da Associação Portuguesa de Linguística, Braga, Portugal, 20-22 November 2008; Fiéis, A., Coutinho, M.A., Eds.; APL: Lisbon, Portugal, 2009; pp. 97-114.

(12) Almeida, E.; Callou, D.; Sobre o uso variável do subjuntivo em português: um estudo de tendência. In Proceedings of the Textos Seleccionados do XXV Encontro Nacional da Associação Portuguesa de Linguística, Braga, Portugal, 22-24 October 2009; Brito, A.M., Silva, F., Veloso, J., Fiéis, A., Eds.; APL: Lisbon, Portugal, 2010; pp. 143-152.

(13) Costa, J.; Martins, A. Scrambling de Média Distância com Advérbios Locativos no Português Contemporâneo. In Proceedings of the Textos Seleccionados do XXIV Encontro Nacional da Associação Portuguesa de Linguística, Braga, Portugal, 20-22 November 2008; Fiéis, A., Coutinho, M.A., Eds.; APL: Lisbon, Portugal, 2009; pp. 225-237.

(14) Gonçalves, P.N.; Branco, A.; Buscador on-line do CILTIL TreeBank. In Proceedings of the Textos Seleccionados do XXV Encontro Nacional da Associação Portuguesa de Linguística, Braga, Portugal, 22-24 October 2009; Brito, A.M., Silva, F., Veloso, J., Fiéis, A., Eds.; APL: Lisbon, Portugal, 2010; pp. 465-473.

(15) Marques, R.; Sobre alguns modificadores nominais do valor modal. In Proceedings of the Textos Seleccionados do XXIV Encontro Nacional da Associação Portuguesa de Linguística, Braga, Portugal, 20-22 November 2008; Fiéis, A., Coutinho, M.A., Eds.; APL: Lisbon, Portugal, 2009; pp. 315-329.

(16) Móia, T.; Expressões de medição temporal: norma, variação e desvio. In Proceedings of the Textos Seleccionados do XXV Encontro Nacional da Associação Portuguesa de Linguística, Braga, Portugal, 22-24 October 2009; Brito, A.M., Silva, F., Veloso, J., Fiéis, A., Eds.; APL: Lisbon, Portugal, 2010; pp. 623-641. 
(17) Pratas, F.; Aquisição da estrutura funcional em caboverdiano. In Proceedings of the Textos Seleccionados do XXIV Encontro Nacional da Associação Portuguesa de Linguística, Braga, Portugal, 20-22 November 2008; Fiéis, A., Coutinho, M.A., Eds.; APL: Lisbon, Portugal, 2009; pp. 367-381.

(18) Barbosa, P.; Flores, C.; Clíticos no Português de herança de falantes bilingues de segunda geração. In Proceedings of the Textos Seleccionados do XXVI Encontro Nacional da Associação Portuguesa de Linguística, Porto, Portugal, 21-23 October 2010; Costa, A., Falé, I., Barbosa, P., Eds.; APL: Lisbon, Portugal, 2011; pp. 81-98.

(19) Braga, D.; Resende Jr., F.G.V.; Módulos de Processamento de Texto Baseados em Regras para Sistemas de Conversão Texto-Fala. In Proceedings of the Textos Seleccionados do XXII Encontro Nacional da Associação Portuguesa de Linguística, Coimbra, Portugal, 2-4 October 2006; Lobo, M., Coutinho, M.A., Eds.; APL: Lisbon, Portugal, 2007; pp. 141-155.

(20) Barbosa, A.I. Para a delimitação da alomorfia derivacional do Português. In Proceedings of the Textos Seleccionados do XXI Encontro Nacional da Associação Portuguesa de Linguística, Porto, Portugal, 28-30 September 2005; Oliveira, F., Barbosa, J., Eds.; APL: Lisbon, Portugal, 2006; pp. 169-181.

(21) Pereira, M.E.L. Amplificação mediática: inscrições linguísticas do dialogismo na recepção de um tratado político internacional. In Proceedings of the Textos Seleccionados do XVII Encontro Nacional da Associação Portuguesa de Linguística, Lisbon, Portugal, 2-4 October 2001; Gonçalves, A., Correia, C.N., Eds.; APL: Lisbon, Portugal, 2002; pp. 354-355.

(22) Cunha, L.F.; Silvano, P.; A interpretação temporal dos infinitivos em orações completivas de verbo. In Proceedings of the Textos Seleccionados do XXI Encontro Nacional da Associação Portuguesa de Linguística, Porto, Portugal, 28-30 September 2005; Oliveira, F., Barbosa, J., Eds.; APL: Lisbon, Portugal, 2006; pp. 303-314.

(23) Branco, T.; Moreira, M.; Castro, A.; Sobre concordância em crianças com Perturbação Específica do Desenvolvimento da Linguagem. In Proceedings of the Textos Seleccionados do XXVI Encontro Nacional da Associação Portuguesa de Linguística, Porto, Portugal, 21-23 October 2010; Costa, A., Falé, I., Barbosa, P., Eds.; APL: Lisbon, Portugal, 2011; pp. 111-124.

(24) Matos, G.; Colaço, M.; As orações coordenadas parentéticas flutuantes como uma instância de adjunção. In Proceedings of the Textos Seleccionados do XXV Encontro Nacional da Associação Portuguesa de Linguística, Braga, Portugal, 22-24 October 2009; Brito, A.M., Silva, F., Veloso, J., Fiéis, A., Eds.; APL: Lisbon, Portugal, 2010; pp. 607-622.

\section{References}

1. Salager-Meyer, F. Scientific publishing in developing countries: Challenges for the future. J. Engl. Acad. Purp. 2008, 7, 121-132. [CrossRef]

2. Salager-Meyer, F. Writing and publishing in peripheral scholarly journals: How to enhance the global influence of multilingual scholars? J. Engl. Acad. Purp. 2014, 3, 78-82. [CrossRef]

3. Dontcheva-Navratilova, O. The Changing Face of Czech Academic Discourse. In The Semiperiphery of Academic Writing. Discourses, Communities and Practices; Bennett, K., Ed.; Palgrave Macmillan: London, UK, 2014; pp. 39-61.

4. Swales, J. Genre Analysis. English in Academic and Research Settings; Cambridge University Press: Cambridge, UK; New York, NY, USA, 1990.

5. Swales, J. English as a Tyranossaurus Rex. World Engl. 1997, 16, 373-382. [CrossRef]

6. Flowerdew, J. Scholarly writers who use English as an additional language: What can Goffman's "Stigma" tell us? J. Engl. Acad. Purp. 2008, 7, 77-86. [CrossRef]

7. Flowerdew, J. Discourse Community, Legitimate Peripheral Participation, and the Non-Native-EnglishSpeaking Scholar. TESOL 2000, 34, 127-150. [CrossRef]

8. Swales, J. Research Genres. Explorations and Applications; Cambridge University Press: Cambridge, UK; New York, NY, USA, 2004. 
9. Curry, M.J.; Lillis, T. Multilingual Scholars and the Imperative to Publish in English: Negotiating Interests, Demands, and Rewards. TESOL 2004, 38, 663-688. [CrossRef]

10. Tardy, C. The role of English in scientific communication: Lingua franca or Tyrannossaurus Rex? J. Engl. Acad. Purp. 2004, 3, 247-269. [CrossRef]

11. Uzuner, S. Multilingual scholars' participation in core/global academic communities: A literature review. J. Engl. Acad. Purp. 2008, 7, 250-263. [CrossRef]

12. Curry, M. J.; Lillis, T. Academic Research Networks: Accessing resources for English-medium publishing. Engl. Specif. Purp. 2010, 29, 281-295. [CrossRef]

13. Pèrez-Llantada, C.; Plo, R.; Ferguson, G.R. "You don't say what you know, only what you can": The perceptions and practices of senior Spanish academics regarding research dissemination in English. Engl. Specif. Purp. 2011, 30, 18-30.

14. Bocanegra-Valle, A. "English is my default academic language". Voices from LSP scholars publishing in a multilingual journal. Engl. Acad. Purp. 2014, 13, 65-77. [CrossRef]

15. Gentil, G.; Séror, J. Canada has two official languages-Or does it? Case studies of Canadian scholars' language choices and practices in disseminating knowledge. J. Engl. Acad. Purp. 2014, 13, 17-30. [CrossRef]

16. Muresan, M.; Pèrez-Llantada, C. English for research publication and dissemination in bi / multilateral environments: The case of Romanian academics. J. Engl. Acad. Purp. 2014, 13, 53-64. [CrossRef]

17. Bardi, M. Learning the practice of scholarly publication in English-A Romanian perspective. Engl. Specif. Purp. 2016, 37, 98-111, (Online early access). [CrossRef]

18. Van Bonn, S.; Swales, J. English and French journal abstracts in the language sciences. Three exploratory studies. J. Engl. Acad. Purp. 2007, 6, 93-108. [CrossRef]

19. Martín Martín, P. A genre analysis of English and Spanish research papers abstracts in experimental social sciences. Engl. Specif. Purp. 2003, 22, 25-43. [CrossRef]

20. Martín Martín, P. The Rhetoric of the Abstract in English and Spanish Scientific Discourse; Peter Lang: Berne, Switzerland, 2005.

21. Lorès, R. On RA abstracts: From rhetorical structure to thematic organisation. Engl. Specif. Purp. 2004, 23, 208-302. [CrossRef]

22. Lorès Sanz, R. Lost (and Gained) in Translation: A Contrastive (English/Spanish) Analysis of Rhetorical and Lexicogrammatical Patterns in Sociology Research Article Abstracts. In Abstracts in Academic Discourse. Variation and Change; Bondi, M., Lorès Sanz, R., Eds.; Peter Lang: Berne, Switzerland, 2014; pp. 85-109.

23. Alonso-Almeida, F. Evidential and Epistemic Devices in English and Spanish Medical Computing and Legal Scientific Abstracts: A Contrastive Study. In Abstracts in Academic Discourse. Variation and Change; Bondi, M., Lorès Sanz, R., Eds.; Peter Lang: Berne, Switzerland, 2014; pp. 21-42.

24. Blanco, C.E. Géneros textuales en las disciplinas: Resúmenes de la Revista de Pedagogía de la Universidad Central de Venezuela 1996-2008. Lexis 2013, XXXVII, 305-340.

25. Diani, G. On English and Italian Research Articles Abstracts: Genre Variation across Cultures. In Abstracts in Academic Discourse. Variation and Change; Bondi, M., Lorès Sanz, R., Eds.; Peter Lang: Berne, Switzerland, 2014; pp. 65-84.

26. Bennett, K. Academic Writing in Portugal; Imprensa da Universidade: Coimbra, Portugal, 2011.

27. Bennett, K. The Erosion of Portuguese Historiographic Discourse. In The Semiperiphery of Academic Writing. Discourses, Communities and Practices; Bennett, K., Ed.; Palgrave Macmillan: London, UK, 2014; pp. 13-38.

28. Johns, T. It is presented initially. Linear dislocation \& inter-language strategies in Brazilian academic abstracts in English and Portuguese. Ilha Desterro 1992, 27, 9-32.

29. Dos Santos, M.B. The textual organization of research paper abstracts in applied linguistics. Text Talk 1996, 16, 481-499. [CrossRef]

30. Canagarajah, A.S. A Geopolitics of Academic Writing; University of Pittsburgh Press: Pittsburgh, PA, USA, 2002.

31. Bennett, K. Introduction. In The Semiperiphery of Academic Writing. Discourses, Communities and Practices; Bennett, K., Ed.; Palgrave Macmillan: London, UK, 2014; pp. 1-9.

32. Bennett, K. Academic Discourse in Portugal: A whole different ballgame? J. Engl. Acad. Purp. 2010, 9, $21-32$. [CrossRef]

33. Instituto Nacional de Estatística. Estatísticas da Comunidade de Países de Língua Portuguesa; INE: Lisboa, Portugal, 2012. 
34. Burgess, S. Centre-Periphery Relations in the Spanish Context. In The Semiperiphery of Academic Writing. Discourses, Communities and Practices; Bennett, K., Ed.; Palgrave Macmillan: London, UK, 2014; pp. 93-104.

35. Bronckart, J.-P. Activité Langagière, Textes et Discours-Pour un Interactionnisme Socio-Discursif; Delachaux \& Niestlé: Lausanne, Switzerland, 1996.

36. Adam, J.-M. En finir avec les types de textes. In Analyse des Discours. Types et Genres, Communication et Interprétation; Ballabriga, M., Ed.; Champs du signe, Editions Universitaires de Toulouse: Toulouse, France, 2001; pp. 25-43.

37. Adam, J.-M. La linguistique textuelle. In Introduction à L'analyse Textuelle des Discours; Armand Colin: Paris, France, 2008.

38. Coutinho, M.A.; Miranda, F. To Describe Genres: Problems and Perspectives. In Genre in a Changing World. Perspectives on Writing; Bazerman, C., Bonino, A., Figueiredo, D., Eds.; The WAC Clearinghouse and Parlor Press: Fort Collins, CO, USA, 2009; pp. 35-55.

39. Tardy, C. Current Conceptions of Voice. In Stance and Voice in Written Academic Genres; Hyland, K., Sancho-Guinda, C., Eds.; Palgrave MacMillan: London, UK, 2012; pp. 34-48.

40. Gray, B.; Biber, D. Current Conceptions of Stance. In Stance and Voice in Written Academic Genres; Hyland, K., Sancho-Guinda, C., Eds.; Palgrave MacMillan: London, UK, 2012; pp. 15-33.

41. Bondi, M. Changing Voices: Authorial Voice in Abstracts. In Abstracts in Academic Discourse. Variation and Change; Bondi, M., Lorès Sanz, R., Eds.; Peter Lang: Berne, Switzerland, 2014; pp. 243-269.

42. Hyland, K. Disciplinary Identities: Individuality and Community in Academic Discourse; Cambridge University Press: Cambridge, UK, 2012.

43. Camacho, J. Null Subjects; Cambridge University Press: Cambridge, UK, 2013.

44. Vladimirou, D. Academic Discourse Practices in Greece. In The Semiperiphery of Academic Writing. Discourses, Communities and Practices; Bennett, K., Ed.; Palgrave Macmillan: London, UK, 2014; pp. 62-74.

45. Yakhontova, T. Cultural and disciplinary variation in academic discourse: The issue of influencing factors. J. Engl. Acad. Purp. 2006, 5, 153-167. [CrossRef]

46. Gillaerts, P.; van de Velde, F. Interactional metadiscourse in research article abstracts. J. Engl. Acad. Purp. 2010, 9, 128-139. [CrossRef]

47. Swales, J.; Feak, C. Abstracts and the Writing of Abstracts; University of Michigan Press: Ann Arbor, MI, USA, 2009.

48. Doró, K. Selling their Research: The Linguistic Realization of Rhetoric Moves in English Thesis Abstracts Written by Hungarian Students. Roman. J. Engl. Stud. 2013, 10, 181-191. [CrossRef] 